\title{
VARIATION IN ZOOPLANKTON DIVERSITY AND ITS RELATIONSHIP WITH ABIOTIC ENVIRONMENT OF A VANDIYUR POND TAMILNADU INDIA
}

\author{
Umamaheswari, K., ${ }^{1}$ M. Chandran ${ }^{2 *}$, K. Rajendran ${ }^{3}$ and G. Chandrn ${ }^{4}$ \\ ${ }^{1}$ Department of Zoology, Thiagarajar College Madurai - 625009. \\ ${ }^{2}$ Department of Zoology, Thiruvalluvar University, Vellore. \\ ${ }^{3}$ Department of Botany, Thiagarajar College Madurai - 625009 \\ ${ }^{4}$ PG Department of Zoology, Madura College, Madurai - 625011 \\ *E.mail: chandranphd1983@gmail.com
}

\begin{abstract}
Ponds, Lakes and Reservoir are most significant water resources with multiple human utilization andecological relevance in which Zooplankton diversity is one of the most important ecological parameters in water quality assessment. It is good indicator of the changes in water quality because they are strongly affected by environmental conditions. In the present study an attempt has been made to study the seasonal variations in the Zooplankton community, its diversity and hydrological parameters of this water body. In the present study, a total of 24 species of Zooplankton were indentified from different classes during August 2014 to January 2015. Among the identified species, Zooplankton showed the complete dominance, especially, zooplankton belonging to four major groups i.e. 9 species of Rotifera, 6 species each of Cladocera, 4 Copepoda and five species of Ostracoda.
\end{abstract}

Keywords: Zooplankton, Bioindicator, water quality.

\section{INTRODUCTION}

Studies on fresh water bodies, natural or manmade have gained much importance in recent years mainly because of their multiple uses. Several workers have attempted to study the hydrobiological profile of varied water bodies with intent of assessing the quality of water zooplankton play a very important role in increasing photosynthesis in some algae which pass through their nutrient rich elementary canal in viable condition. Zooplankton acts as bio-indicator of water quality as well as quantification of primary energy transfer from producer to primary consumer (Dulic et al., 2006). Kolhe et al., 2013 also observed the zooplankton communities respond more quickly to environment variations. Therefore the water quality is a major factor in determining the welfare of the society (Dwivedi and Pathak, 2000). It also plays a vital role in governing the production of planktonic biomass. The management of any aquatic ecosystem is a means of conservation of fresh water habitat with an aim to maintain the water quality or to rehabilitate the physico-chemical and biological settling of water (Ravi Kumar et al., 2005). Based on the above mentioned facts, it is suggested to make an inventory of the physicochemical parameters and zooplankton diversity of vandiyur pond, located in Madurai.

\section{MATERIALS AND METHODS}

\subsection{Study Area}

Vandiyur pond was selected for my research work actually; it is a small aquatic pond with a minimum depth of pond about 25 feet. It is located just east zone of Madurai town. In which possess the common fishes likeCatlacatla, Rohu and kendai. This pond water is used only for the agriculture and fish farm.

\subsection{Sample Collection}

The water sample was collected from the pond surface once in the early hours of the day from August 2014 to January 2015. The water samples were collected using one litre container for the estimation of water quality parameters. The collected samples were immediately taken to the laboratory for analysis. The estimation was done by using the standard book of Kumar and Kakrani (2000).

\subsection{Biological Analysis}

Zooplankton samples were collected by filtering 300 litres of water from the surface of the water body through plankton net ( $40 \mu \mathrm{m}$ mesh size) and which was fixed immediately with $4 \%$ ormalin. The systematic identification of zooplankton was made by using standard keys of Dhanapathi (2000) 
and Altaff (2004). The quantitative analysis of planktonic organisms was carried out using Sedgwick Rafter's plankton counting chamber.

\section{RESULTS AND DISCUSSION}

The seasonal fluctuations of pond water quality parameters have a markedinfluence on the numerical abundance of zooplankton. Jeppesenet al. (2002) has stated that the enormous and diversity of zooplankton vary according to limnological features and the trophic state of freshwater bodies.

\subsection{Biological parameters}

\subsubsection{Qualitative study of zooplankton in vandiyur pond}

In a pond system, a total of 24 species of zooplankton have been exposed that belongsto four major groups. They were included as follows,
Rotifera- 9, species Cladocera- 6, species Copepoda 4 and species Ostracoda - 5 species.

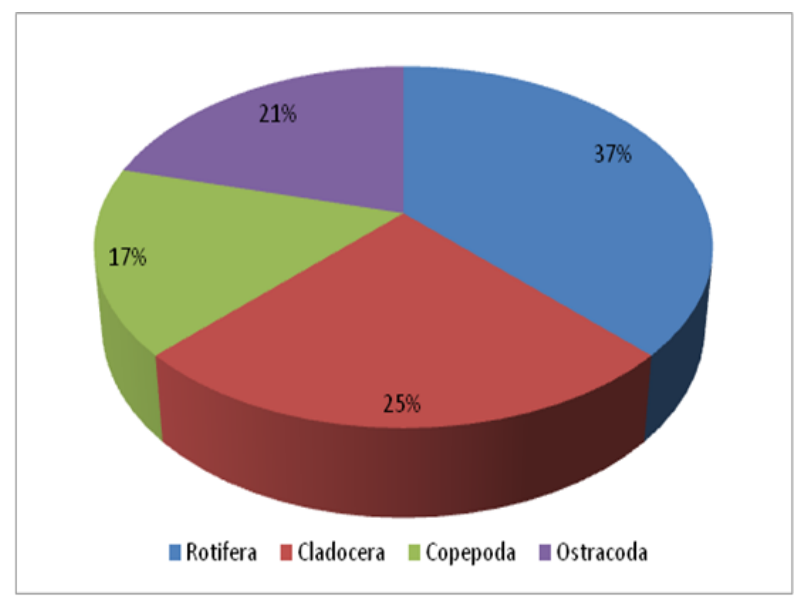

Fig. 1. Zooplankton abundance in vadiyur pond

Table 1. Monthly Variations in the Physico-chemical parameters of the Vandiyur Pond.

\begin{tabular}{lcccccc}
\hline \multicolumn{1}{c}{ Parameter } & $\begin{array}{c}\text { August } \\
\mathbf{2 0 1 4}\end{array}$ & $\begin{array}{c}\text { September } \\
\mathbf{2 0 1 4}\end{array}$ & $\begin{array}{c}\text { October } \\
\mathbf{2 0 1 4}\end{array}$ & $\begin{array}{c}\text { November } \\
\mathbf{2 0 1 4}\end{array}$ & $\begin{array}{c}\text { December } \\
\mathbf{2 0 1 4}\end{array}$ & $\begin{array}{c}\text { January } \\
\mathbf{2 0 1 5}\end{array}$ \\
\hline $\begin{array}{l}\text { Temperature } \\
\left({ }^{\circ} \mathrm{C}\right)\end{array}$ & & & & & & \\
$\begin{array}{l}\text { Air } \\
\text { water }\end{array}$ & 27 & 28 & 27 & 27 & 29 & 30 \\
$\mathrm{PH}$ & 7.2 & 7.6 & 7.8 & 8.1 & 7.8 & 8.0 \\
$\begin{array}{l}\text { Total Hardness } \\
\text { (ppm) }\end{array}$ & 132.12 & 142.27 & 98.56 & 67.12 & 58.49 & 62.10 \\
$\begin{array}{l}\text { Dissolved } \\
\begin{array}{l}\text { Oxygen } \\
\text { (mg/l) }\end{array}\end{array}$ & & & & & & \\
$\begin{array}{l}\text { Free } \\
\text { dioxide } \\
\text { (mg/l) }\end{array}$ & 6.2 & 5.8 & 6.2 & 4.2 & 5.8 & 6.9 \\
$\begin{array}{l}\text { Total Alkalinity } \\
\text { (ppm) }\end{array}$ & 198.00 & 212.16. & 196.14 & 168.12 & 182.00 & 89.17 \\
$\begin{array}{l}\text { Salinity (ppm) } \\
\text { Chlorinity } \\
\text { (ppm) }\end{array}$ & 222.03 & 196.15 & 165.13 & 145.22 & 156.28 & 102.36 \\
$\begin{array}{l}\text { Phosphate } \\
\text { (mg/l) }\end{array}$ & 121.10 & 98.27 & 89.23 & 123.00 & 131.00 & 89.12 \\
\hline
\end{tabular}

\subsubsection{Quantitative study of zooplankton in vandiyur} pond

In the present work was assessed, $B$. calyciflorus was found to be more in number during the month of August 2014 and B. forficulain the month of November 2014 (3units/ml). The other species were recorded in low number. B. rubens was observed only during August 2014. The enormous of rotifers and their community characteristics are used as effective indicators of environmental changes, such as, acidity, food level and humidity etc. (Attayde and Bozelli, 1998). The number of cladocerans recorded was minimum during the study period. Ceriodaphnia cornuta was recorded during the entire period of study. Their presence indicates the health of the ecosystem, as it forms the basic food item for fishes. Mesocyclops aspericornis was 
observed maximum in the month of November 2014 (20 units $/ \mathrm{ml}$ ) and minimum in January 2015 (5 units/ml). Kumar (1999) reported that cyclopsserve as the most suitable pollution tolerant indicator. Heliodiaptomusviduuswas found in range from 2 units/ml in August 2014 to 10 units/ml in December 2014. Diaptomusnauplius showed variations from 3 units $/ \mathrm{ml}$ in December to 10 units/ml in January 2015. The ostracod was represented by only one species, Stenocypris major was observed in all the months (1 unit/ml) except November 2014.

In the air temperature was ranged from 27 to $30^{\circ} \mathrm{C}$ and water temperature from 25 to $29^{\circ} \mathrm{C}$. Kumar and Kakrani (2000) opined that the rise in temperature of water elevates the metabolic activity of an organisms. It also influences the growth and distribution of plankton. Welch (1952) has observed that smaller the water body, more quickly to react the changes in atmospheric temperature. The $\mathrm{pH}$ of the water body showed alkaline in nature ie. 7.2 to 8.0This range is good for growth of aquatic organisms (Lendhe and Yeragi, 2004). Bell (1971) has stated the $\mathrm{pH}$ ranges between 6.5 to 9.0 provides an adequate protection to the life of fresh water organisms. Jhingran (1991) reported that $\mathrm{pH}$ ranges between 6.0 to 8.5 indicates medium productivity, more than 8.5 highly productive and less than 6.0 low productive nature of water body. Total hardness ranged between $58 \mathrm{ppm}$ in December 2014 and $142.27 \mathrm{ppm}$ in August 2014. Fishes have been found to susceptible to diseases when hardness is below 20 $\mathrm{ppm}$. If it ranged more than $300 \mathrm{ppm}$, it affects fish production due to more $\mathrm{pH}$ as reported by Das (1996). Dissolved oxygen content in the water sample ranged from 4.2 to $6.09 \mathrm{mg} / \mathrm{l}$.Mustafa and Ahmad (1985) opined the partial of 02 dissolved in water depends upon the partial pressure of gas in the air close to water, rate of photosynthesis and oxygen holding capacity of water. Tarzwell (1957) reported that for supporting life, minimum of $3 \mathrm{mg} / \mathrm{l}$ DO is required. Free Co2 ranged from 2.9 to $4.9 \mathrm{mg} / \mathrm{l}$ during the study period. In morning sample, there is an accumulation of free $\mathrm{Co} 2$ due to overnight community respiration. Salasker and Yeragi (2003) noted that slightly increased Co2 in winter season. Free $\mathrm{Co} 2$ is essential for photosynthesis and its concentration affects the aquatic fauna and its productivity. The total alkalinity was ranged from 89.17 to $212.16 \mathrm{ppm}$. In the water body, the alkalinity is imparted by number of bases viz., carbonates, bicarbonates, hydroxides, phosphates, nitrates, silicates, borates etc., (Kumar and Kakrani, 2000). The fluctuation in salinity is probably due to fluctuation in total solids (Boyd and Tucker, 1998).
The minimum value of chlorides (89.12 ppm) was found in the month of January 2015 and the maximum value of $131.00 \mathrm{ppm}$ during the month of December 2014 was recorted. Chloride content above $250 \mathrm{ppm}$ makes water salty in taste; however a level upto $1000 \mathrm{ppm}$ is safe for human consumption (Kumar and Kakrani, 2000). The phosphatecontent of water sample showed 0.01 to $0.06 \mathrm{mg} / \mathrm{l}$. It is an essential nutrient, play a vital role inbiological activities of aquatic organisms. Lendhe and Yeragi (2004) reported the range ofphosphates from $1.20 \mathrm{mg} / \mathrm{l}$ to $3.70 \mathrm{mg} / \mathrm{l}$ in Phirangekharbav lake.

\section{CONCLUSION}

An inverse relationship was observed zooplankton abundance. The managed fish culture pond which wasperiodically limed, manured and fertilised showed greater zooplankton being the dominant group. Whereas theunmanaged village pond showed a less diverse and eutrophic condition,zooplankton being the dominant group. It implies that alarge amount of ecological niches are remaining void and unutilized in village ponds. Whereas all the available ecological niches are beingeffectively utilized by the stocked fishes and periodically replenishedby fertilization in the managed fish culture pond. Therefore selectivestocking with appropriate species at low densities and extensive fishculture practices in the village ponds has ample scope. Adoption andtransformation of such village ponds by scientific management practicesinto semi-intensive fish culture ponds may prove to be an ecologicallyefficient, financially feasible and socially viable venture.

\section{REFERENCES}

Altaff, K., (2004), A manual of Zooplankton. University grants commission, New Delhi, Pp 1145.

Attayade, J.L. and R.L. Boryelli, (1998), Assessing the indicator properties of zooplankton assemblages to disturbance gradients by canonical correspondence analysis. Can. J. fish.Aquat.Sci, 55: 1789-1797

Boyd, C.E, and C.S.Tucker, (1998), Pond aquaculture water quality management.Kluwer academic publisher, London.

Das, R.K, (1996), Monitoring of water quality, its importance in disease control, paper presented in Nat. Workshop on fish and prawn disease, epizootics and quarantine adaptation in India. CICFRI: 51-55.Delhi. 
Dhanapathi, M.V.S.S.S, (2000). Taxonomic notes on the Rotifers from India-IAAB publication, Hydrabad: 175.

Dulic, Z., V. Veramitrovic-Tutundzic., Z. Markovic and I. Zivic, (2006).Monitoring water quality using zooplankton organisms as bioindicators at the Dubica fish farm, Serbia.Arch. Biol.Sci., Belgrade, 58(4):245-248.

Dwivedi, S.L and V. Pathak, (2000).Studies of water quality of Mandakini rules in Chikrakoot for irrigation purpose.Indian J. Env. Prot, 27 (8): 751-754.

Jeppesen, E., J.P. Jensen and M. Sondergard(2002). Response of phytoplankton, zooplankton and fist to oligotrophication : an 11. year study of 23 Danish lakes. Aquatic ecosystems health and management, 5: 31-43.
Jhingran, V.G. (1974).Fish and fisheries of India.Hindustan publishing corporation, New Delhi.

Kolhe, BG., SP. Zambare., SB. Andhale and MS. Rane(2013).An estimation of plankton population of Godavari river with reference to pollution. BiosciDiscov, 4(1): 117-120.

Kumar, A, (1999). Impact of Industrial effluents on the ecology of river Ganga in Bihar "Ecology of polluted waters and Toxicology" (Ed. K.D.Mishra) TechnosciencePubl.Jaipur, Pp.87102.

Kumar, U. and BhanuKakrani, (2000). Water environment and pollution. Agrobios, India. Pp $1-258$.

Ravikumar, M., S. Manjappa., B.R. Kiran, E.T. Puttaiah and I. Ramesh, (2005). Hydrography of Begali tank near Harapanahali, Devangere District, Indian J. Environmental Prot, 27 (5): 454-458. 